\title{
FORMATION OF A NEW BRITISH ANTI-V.D. ORGANIZATION
}

The need for a non-governmental association to support the Government's anti-venereal measures was recognized by the Royal Commission on Venereal Diseases, which reported in 1916 and recommended that the body then known as The National Council for Combating Venereal Diseases (N.C.C.V.D. below) be used as the chief agency for education of the general public in the dangers of venereal diseases and in measures for their avoidance and cure. Later (about 1924) the N.C.C.V.D. changed its name to The British Social Hygiene Council (B.S.H.C. below) and continued to receive direct annual grants, first from the Local Government Board and then from its successor, the Ministry of Health, until the year ending March 31, 1930, when the B.S.H.C. was instructed that in future, under the provisions of the Local Government Act of 1929, it must look for financial grants to the County Councils and County Borough Councils, the authorities responsible for carrying out the provisions of the Public Health (Venereal Diseases) Regulations, 1916.

The amount of the Ministry of Health's annual grant from March 31, 1919, to March 31, 1930, had averaged about $£ 10,000$, but in 1923 to 1929 the average had been about $£ 7,900$. Under the new arrangement the B.S.H.C. fared worse than when the Ministry paid directly.

The B.S.H.C. continued to be the central agency for anti-venereal propaganda until 1942 when this work was transferred to the Central Council for Health Education (C.C.H.E. below); since then the C.C.H.E. and the Ministry have collaborated in educating the public in this subject, and during the war very large sums were spent.

So far as education of the public by advertisement and pamphlet is concerned the present arrangement has no doubt been reasonably satisfactory, but there are a number of ways outside the scope of the C.C.H.E's terms of reference in which non-governmental organizations could help in combating venereal diseases. An efficient antivenereal disease organization should not only educate the public in the facts about V.D. but should also draw attention to conditions, customs, conduct, and other factors which affect their spread, and in this respect the C.C.H.E. may not have been able to fill the role of an efficient anti-venereal organization.

Further, it appears that the C.C.H.E. in its new constitution may not be able to interest itself in the international aspect of anti-venereal disease work, a branch of activity which a maritime nation with close contacts with innumerable foreign ports cannot afford to neglect. It is felt by the International Union against Venereal Diseases (U.I.P.V. below) that Great Britain should be more strongly represented there and should exert a stronger influence than hitherto.

With regard to the constitution of this proposed organization, it is felt that it should be mainly composed of associations whose work, directly or indirectly, reduces the spread of venereal diseases, and that it should give opportunities for membership to individuals not necessarily connected with or representative of organized bodies. Considering that venereal diseases are symptoms of social disorder and personal unhappiness it is clear that very few organizations interested in the promotion of social welfare can fail to be interested in the venereal factor.

Moreover, it is certain that each type of welfare organization must have its own particular experience in matters affecting the contraction of venereal disease, and that the contributions to the pool of knowledge collected by a joint organization such as now adumbrated cannot fail to be more valuable than would be those of isolated individuals. On the other hand, many organizations could doubtless take from discussions in the joint organization information which would be valuable to them in their specialized work.

The Council of the Medical Society for the Study of Venereal Diseases appointed a subcommittee to inquire of various potentially interested bodies whether they would be prepared to attend, without prejudice or commitment, a conference 
to discuss the possible formation of a new organization. The replies received indicated a sufficiently strong actual and potential interest in the scheme and a conference was accordingly arranged for April 17, 1951.

Through the kindness of the British Medical Association, the meeting was held in B.M.A. House, and the organizers were extremely fortunate in securing the services of Sir Allen Daley as Chairman.

In his opening remarks Sir Allen stressed that the venereal diseases are still a very serious menace to health and expressed his satisfaction that voluntary efforts should have led to the convening of such a conference. After further explanations of the need for such a new society and clarification of the position of the British Social Biology Council and the Central Council for Health Education, the Chairman directed the discussion to the aims and objects of such a new body.

Many speakers brought out important points during the debate and it was finally agreed that the aims and objects should be :-

1. To study conditions that favour the spread of venereal infections and methods of combating them.

2. To assist bodies whose activities have the effect of combating the spread of venereal disease.

3. To encourage the spread of knowledge of the facts about venereal diseases.

4. To collaborate with other national and international organizations having similar objectives.

Col. L. W. Harrison then proposed that a new organization be formed and Dr. G. L. M. McElligott seconded the motion. The proposition was put to the meeting and carried.

On a proposition by Mrs. E. French, British Social Biology Council, and Miss E. M. Gosling, Royal College of Nursing, Dr. F. R. Curtis was unanimously elected Hon. Secretary and pro tem. Hon. Treasurer.

It was then decided to appoint a committee of about twelve to consider the detailed problems of setting up the new organization and the following were duly elected :
1. Dr. J. A. Scott

2. Dr. R. Forgan

3. Col. L. W. Harrison

4. Mr. A. J. King

6. Mr. F. D. Dawtry

7. Dr. Letitia Fairfield

8. Mrs. E. French

9. Rev. R. More O'Ferrall

10. Miss E. M. Steel
5. Dr. G. L. M. McElligott

Chairman.

M.S.S.V.D.

National Association of Probation Officers.

Invalid Children's Aid Association.

British Social Biology Council.

Apostleship of the Sea. Church of England Moral Welfare Council.

with representatives of the Royal College of Nursing, Institute of Almoners, and Missions to Seamen, to be nominated by the respective organizations.

It will be seen that the new society was broadly based on the support of a diversity of important bodies which augurs well for its future.

The question of a title offered difficulties and it was finally left to the Committee to select a suitable name.

The members of the new society will be drawn from interested societies, authorities, and organizations, and associate membership without voting power will be available to interested individuals. It was further agreed that members who shall have joined by December 31, 1951, shall be founder members, and that all subsequent members will be elected at Annual General Meetings.

Finance presented a thorny problem, but during the discussion Col. Harrison promised a donation of $£ 100$ and Mr. A. J. King, Hon. Treasurer to the M.S.S.V.D., said he thought that his Society would give sympathetic consideration to a further donation. The question of annual subscription was left to the Committee to decide.

It was agreed that the new society should be represented at the meeting of the Union Internationale contre le Peril Venérien in Paris at the end of May, 1951, and Mr. A. J. King was nominated as the representative.

At the conclusion of the meeting Sir Allen Daley was accorded a very hearty vote of thanks for giving up his time to take the chair and for conducting the meeting so skilfully and expeditiously.

Postscript.-Since the Conference the Committee has decided that the new Society shall be called The British Federation against the Venereal Diseases, and Col. L. W. Harrison has been appointed Hon. Treasurer. 